\title{
Production of Candida utilis Biomass and Intracellular Protein Content: Effect of Agitation Speed and Aeration Rate
}

\author{
Rosma, A.* and Ooi, K. I. \\ Food Technology Division, School of Industrial Technology, \\ Universiti Sains Malaysia, 11800 Penang, Malaysia. \\ Email: rosmah@usm.my
}

\begin{abstract}
The effects of agitation speed and aeration rate on the Candida utilis biomass and the intracellular protein content were investigated in this study. C. utilis inoculum of $10^{6} \mathrm{cells} / \mathrm{mL}(7.8 \% \mathrm{v} / \mathrm{v})$ was cultured in $1.5 \mathrm{~L}$ pineapple waste medium $(3$ $\%$ Brix) in a $2-\mathrm{L}$ fermentor for $30 \mathrm{~h}$ at $30^{\circ} \mathrm{C}$. Agitation speed and aeration rate have significant effects on the dissolved oxygen concentration, which in turn affect the cell growth and the intracellular protein content. The agitation speed of $100,300,500,700$ and $900 \mathrm{rpm}$ was employed. The highest yield of protein content ( $1.2 \mathrm{~g} / \mathrm{L} \mathrm{media)}$ and total biomass $(7.8 \mathrm{~g} / \mathrm{L}$ media) were resulted from yeast cultivation with agitation speed of $900 \mathrm{rpm}$. Thus, the effects of aeration rate $(0.5,1.0,2.0$ and $3.0 \mathrm{~L} / \mathrm{min})$ were studied at agitation speed of $900 \mathrm{rpm}$. A maximum yield of protein content $(1.6 \mathrm{~g} / \mathrm{L}$ media) and biomass (9.5 g/L media) were attained at aeration rate of $2.0 \mathrm{~L} / \mathrm{min}$.
\end{abstract}

Keywords: Candida utilis, agitation, aeration, pineapple waste, intracellular protein

\section{INTRODUCTION}

Yeast extract has been recognized for its role as flavor enhancers contributed by its nucleotides and amino acid components. It has been widely used in meat sauces and flavor enhancers (Nagodawithana, 1992). Utilization of sucrose or glucose as carbon source is not economical in production of yeast extract, and less expensive carbohydrate source would be beneficial. Pineapple (Ananas comosus) waste is rich in sucrose, the disaccharide most easily utilized by yeast cells (Lee et al., 2001). There is approximately 17,000 hectare of land under pineapple cultivation in Malaysia, producing about 0.25 million tones of fruits. Most of the pineapples are consumed as either fresh products or processed fruit. Of the whole fruits, only $20 \%$ is canned, while the remainder, in the form of peeled skin, core, base and crown is discharged as waste (Hutagalung et al., 2002). In the processing of pineapple, only high-quality fruits are selected while the low-quality one been left out as the market of the fruit is not so encouraging (Kenji et al., 1999). Therefore, it is anticipated that the medium from pineapple waste can be utilized for the production of intracellular protein from Candida utilis. Kenji et al., (1999) had investigated the utility of pineapple waste material as low-cost substrate for ethanol fermentation by Zygomonas mobils while Nigam (1998) had produced single cell protein from pineapple cannery effluent. To be economically feasible, optimum culture condition for the production of maximum biomass and intracellular protein is necessary. In general, the environmental conditions, such as temperature, dissolved oxygen, $\mathrm{pH}$ and so on are important factors which have significant influence on the biomass production. Agitation speed and aeration rate are *Corresponding author the two factors affecting dissolved oxygen concentration, which in turn affect the biomass and intracellular protein content (Lee et al., 2001). Therefore, the objective of this research is to study the effect of agitation speed and aeration rate on the $C$. utilis biomass and protein content yields cultivated in pineapple waste material.

\section{MATERIALS AND METHODS}

\section{Microorganism and inoculum preparation}

Candida utilis ITM 1017 was obtained from the Culture Collection Centre of Universiti Teknologi Mara, reactivated, maintained on YEPG slants at $4^{\circ} \mathrm{C}$ and reactivated every 2 months. Loopfuls of Candida utilis were used to inoculate $50 \mathrm{~mL}$ of pineapple waste medium, incubated at $30{ }^{\circ} \mathrm{C}, 100 \mathrm{rpm}$ for $18 \mathrm{~h}$, to obtain $10^{6}$ cells $/ \mathrm{mL}$.

\section{Pineapple waste medium}

Pineapple waste consisting of peels, cores and unwanted parts of the fruit was obtained from a local fruit stall, washed and cut into smaller pieces before the addition of distilled water at a ratio of $1: 1$ (w:v). The extract was obtained through heat treatment with an autoclave at 121 ${ }^{\circ} \mathrm{C}, 15 \mathrm{psi}$ for $15 \mathrm{~min}$. The extract was then filtered using filter papers Whatman No. 3 and Whatman glass microfiber (GF/C). Pineapple waste extract was diluted to $3 \%$ Brix and the $\mathrm{pH}$ was fixed at $\mathrm{pH}$ 4.5. Every $\mathrm{g}$ pineapple waste will produce $1.0 \mathrm{~mL}$ medium with a total solid content of $3 \%$ Brix. 


\section{Fermentation}

About $7.8 \%(v / v)$ inoculum was used as seed culture. Cultivations were conducted using a 2-L benchtop fermentor (B. Braun Biotech International, Switzerland) with the working volume of $1.5 \mathrm{~L}$ at $30^{\circ} \mathrm{C}$ for $30 \mathrm{~h}$. The $\mathrm{pH}$ was automatically controlled at $\mathrm{pH}$ 4.5. Foaming was controlled using antifoam 289 (Sigma, Germany). Optimization experiment was carried out with one parameter at a time. Firstly, the effect of agitation speed $(100,300,500,700$ and $900 \mathrm{rpm})$ was studied at a fixed aeration rate of $1.0 \mathrm{~L} / \mathrm{min}$. The highest agitation speed studied was $900 \mathrm{rpm}$ due to limitation of the fermentor. Secondly, the effect of aeration rate $(0.5,1.0,2.0$ and 3.0 $\mathrm{L} / \mathrm{min}$ ) was studied at an optimum agitation speed.

\section{Analytical methods}

Cell growth as dry weight of biomass was determined gravimetrically. A volume of culture was centrifuged and washed twice before drying at $70{ }^{\circ} \mathrm{C}$ until constant weight reached. The reducing sugar content of the medium was determined using DNS method (Miller, 1959). Yeast extract was obtained by mechanical rupturing of the cells, according to Loo et al. (2002). Yeast cell protein content of the yeast extract was determined by the Biuret method (Robinson and Hodgen, 1940).

\section{RESULTS AND DISCUSSION}

\section{Effects of agitation speed}

The growth of Candida utilis in pineapple waste medium was low in the initial 5-12 $\mathrm{h}$ regardless of the agitation speed, possibly due to adaptation of the microorganisms. After $12 \mathrm{~h}$, however, growth varied and much higher biomass was obtained at higher agitation speed (Figure 1). After $30 \mathrm{~h}$ of fermentation, the biomass obtained from agitation speed of $700 \mathrm{rpm}$ was $7.93 \mathrm{~g} / \mathrm{L}$ and that of 900 $\mathrm{rpm}$ was $7.83 \mathrm{~g} / \mathrm{L}$. At low agitation speed (100 rpm), biomass slightly decreased at the end of the fermentation. This suggested that shortage of oxygen and limitation of substrate (Figure 2) lead to degradation of cells. As the agitation speed increases, the biomass obtained increases and at a higher agitation speed, more oxygen was incorporated into the medium and lead to progressive growth of $C$. utilis.

C. utilis depleted reducing sugar in cultivation media after $5 \mathrm{~h}$ of cultivation (Figure 2). About $96-98 \%$ of reducing sugar equivalent to glucose in the pineapple waste medium was used-up by the $C$. utilis after $30 \mathrm{~h}$ fermentation (Table 1). Calculated yield of biomass was the highest at the agitation speed of $700 \mathrm{rpm}$, i.e. $0.66 \mathrm{~g}$ biomass produced per g glucose-equivalent reducing sugar.

The yeast cell protein content increased slowly from 12 to $30 \mathrm{~h}$ with a maximum at $30 \mathrm{~h}$ (Figure 3 ). The intracellular yeast protein was determined to be the highest at $900 \mathrm{rpm}$, i.e. $15.5 \%$ (w/w of biomass), which corresponded to $1.22 \mathrm{~g}$ protein per $\mathrm{L}$ medium. A higher agitation speed increased the amount of dissolved oxygen and dispersion of macromolecules in the medium. It might, therefore, contribute to the greater growth and intracellular protein content.

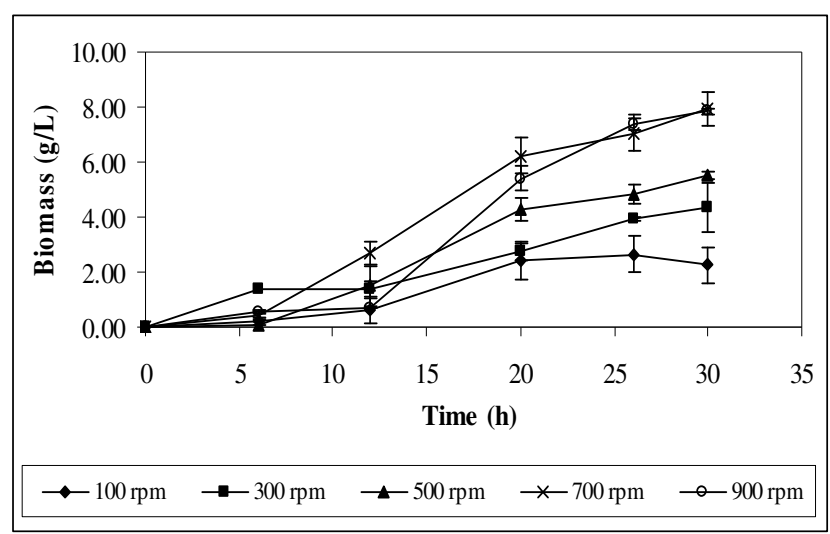

Figure 1: Effects of agitation speed on biomass of $C$. utilis grown in pineapple waste medium. Fermentation was carried out in $1.5 \mathrm{~L}$ media at $30^{\circ} \mathrm{C}$ with an aeration of $1 \mathrm{~L} / \mathrm{min}$ for $30 \mathrm{~h}$. Data are mean values \pm standard errors of triplicate samples

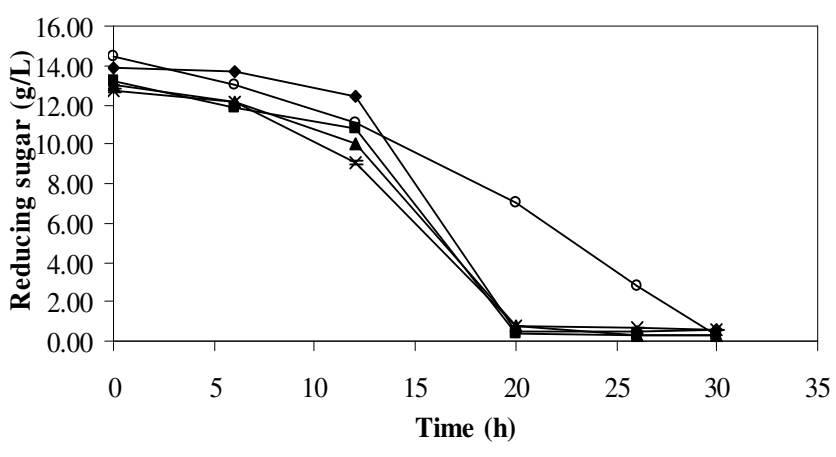

$\multimap 100 \mathrm{rpm} \rightarrow-300 \mathrm{rpm} \rightarrow 500 \mathrm{rpm} \quad \leftarrow 700 \mathrm{rpm} \quad 0900 \mathrm{rpm}$

Figure 2: Effects of agitation speed on substrate consumption by of $C$. utilis in pineapple waste medium. Fermentation was carried out in $1.5 \mathrm{~L}$ media at $30^{\circ} \mathrm{C}$ with an aeration of $1 \mathrm{~L} / \mathrm{min}$ for $30 \mathrm{~h}$. Data are mean values \pm standard errors of triplicate samples

\section{Effects of aeration rate}

With operating temperature and agitation speed maintained at $30{ }^{\circ} \mathrm{C}$ and $900 \mathrm{rpm}$, respectively, the effects of aeration rate were investigated by comparing performance at four aeration rates; 0.5, 1.0, 2.0 and 3.0 $\mathrm{L} / \mathrm{min}$. Biomass production increased with the increase of aeration rate, reaching the maximum value of $9.50 \mathrm{~g} / \mathrm{L}$ media at aeration rate of $2.0 \mathrm{~L} / \mathrm{min}$ (Figure 4).

Substrate consumption ranges was lowest at the aeration rate of $3.0 \mathrm{~L} / \mathrm{min}$, with only $90.7 \%$ of reducing sugar consumed (Table 2 and Figure 5). Calculated yield of biomass was $0.81 \mathrm{~g}$ per g glucose-equivalent reducing 
Table 1: Effects of agitation speed on total substrate consumption, biomass and yeast cell protein content

\begin{tabular}{cccccc}
\hline $\begin{array}{c}\text { Agitation speed } \\
\text { (rpm) }\end{array}$ & $\begin{array}{c}\text { Total substrate } \\
\text { consumption (\%) }\end{array}$ & $\begin{array}{c}\text { Biomass } \\
\text { (g/L media) }\end{array}$ & Yield of biomass $^{\mathbf{a}}$ & $\begin{array}{c}\text { Protein } \\
\text { (g/L media) }\end{array}$ & ${\text { Yield of } \text { protein }^{\text {b }}}^{\mathbf{g} \text { /L }}$ \\
\hline 100 & 96.1 & 2.25 & 0.17 & 0.34 & 0.03 \\
300 & 98.1 & 4.35 & 0.34 & 0.56 & 0.04 \\
500 & 97.8 & 5.53 & 0.43 & 0.67 & 0.05 \\
700 & 95.4 & 7.37 & 0.66 & 1.06 & 0.09 \\
900 & 97.9 & 7.83 & 0.55 & 1.22 & 0.09 \\
\hline
\end{tabular}

${ }^{a}$ Yield of biomass: $g$ biomass per $g$ glucose-equivalent reducing sugar

${ }^{b}$ Yield of protein: $g$ protein per g glucose-equivalent reducing sugar

Table 2: Effects of aeration rate on total substrate consumption, biomass and yeast cell protein content

\begin{tabular}{cccccc}
\hline $\begin{array}{c}\text { Aeration rate } \\
\text { (L/min) }\end{array}$ & $\begin{array}{c}\text { Total substrate consumption } \\
(\%)\end{array}$ & $\begin{array}{c}\text { Biomass } \\
(\mathbf{g} / \mathbf{L} \text { media) }\end{array}$ & $\begin{array}{c}\text { Yield of } \\
\text { biomass }\end{array}$ & $\begin{array}{c}\text { Protein } \\
\text { (g/L media) }\end{array}$ & $\begin{array}{c}\text { Yield of } \\
\text { protein }^{\text {b }}\end{array}$ \\
\hline 0.5 & 97.2 & 6.38 & 0.43 & 0.87 & 0.06 \\
1.0 & 97.9 & 7.83 & 0.55 & 1.22 & 0.09 \\
2.0 & 94.7 & 9.50 & 0.81 & 1.63 & 0.14 \\
3.0 & 90.7 & 8.70 & 0.73 & 1.20 & 0.10 \\
\hline
\end{tabular}

a Yield of biomass: $\mathrm{g}$ biomass per $\mathrm{g}$ glucose-equivalent reducing sugar

${ }^{b}$ Yield of protein: $g$ protein per g glucose-equivalent reducing sugar

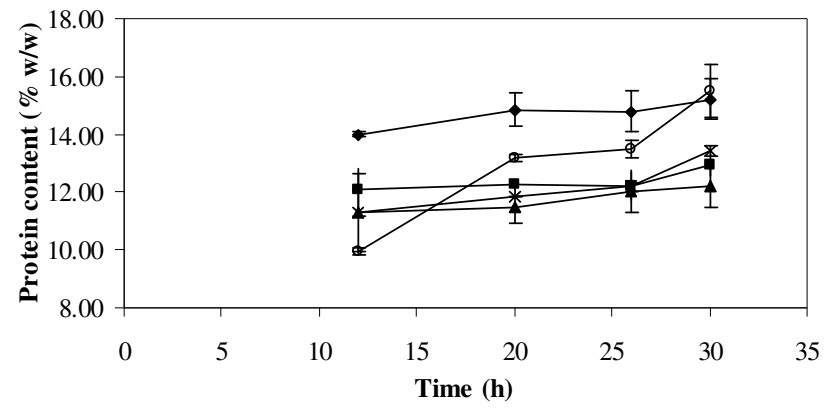

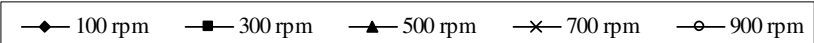

Figure 3: Effects of agitation speed on intracellular protein content of $C$. utilis grown in pineapple waste medium. Fermentation was carried out in $1.5 \mathrm{~L}$ media at $30^{\circ} \mathrm{C}$ with an aeration of $1 \mathrm{~L} / \mathrm{min}$ for $30 \mathrm{~h}$. Data are mean values \pm standard errors of triplicate samples

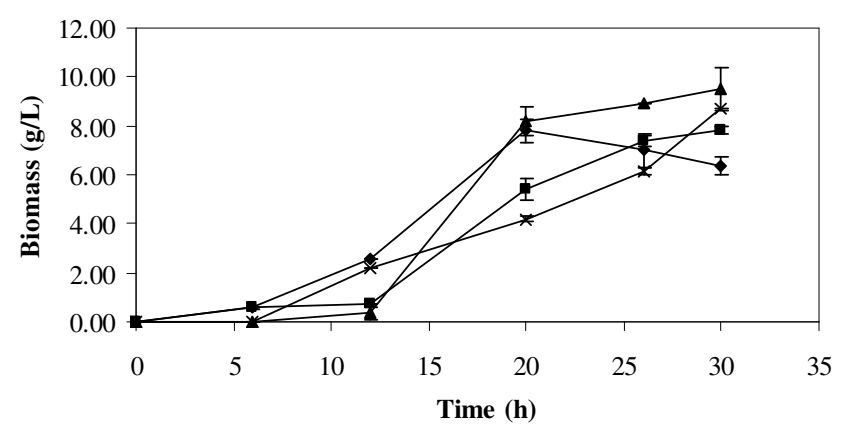

$\multimap 0.5 \mathrm{~L} / \mathrm{min} \rightarrow-1.0 \mathrm{~L} / \mathrm{min} \rightarrow 2.0 \mathrm{~L} / \mathrm{min} \quad \rightarrow 3.0 \mathrm{~L} / \mathrm{min}$

Figure 4: Effects of aeration rate on biomass of $C$. utilis grown in pineapple waste medium. Fermentation was carried out in $1.5 \mathrm{~L}$ media at $30{ }^{\circ} \mathrm{C}$ with an agitation of $900 \mathrm{rpm}$ for $30 \mathrm{~h}$. Data are mean values \pm standard errors of triplicate samples

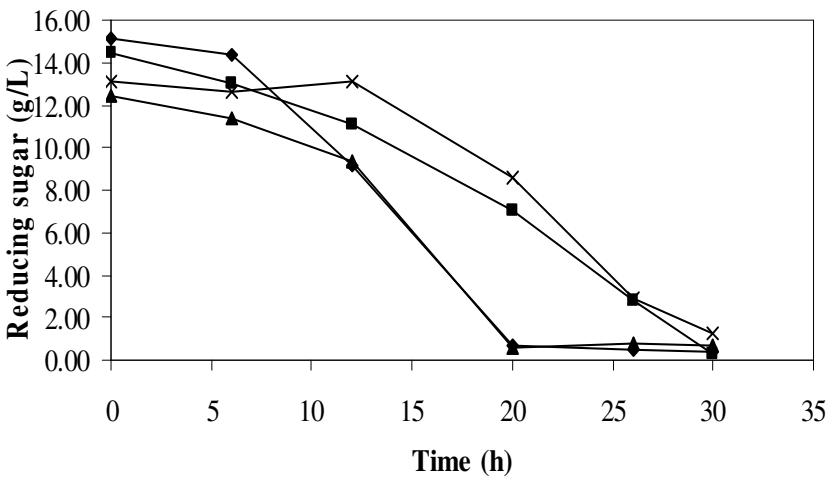

$\rightarrow 0.5 \mathrm{~L} / \mathrm{min} \quad \longrightarrow-1.0 \mathrm{~L} / \mathrm{min} \quad 2.0 \mathrm{~L} / \mathrm{min} \quad-3.0 \mathrm{~L} / \mathrm{min}$

Figure 5: Effects of aeration rate on substrate consumption by of $C$. utilis in pineapple waste medium. Fermentation was carried out in $1.5 \mathrm{~L}$ media at 30 ${ }^{\circ} \mathrm{C}$ with an agitation of $900 \mathrm{rpm}$ for $30 \mathrm{~h}$. Data are mean values \pm standard errors of triplicate samples

sugar at the aeration rate of $2.0 \mathrm{~L} / \mathrm{min}$, which was higher than the yield of $C$. utilis grown in pineapple canning effluent of $0.30-0.48 \mathrm{~g}$ dry biomass per $\mathrm{g}$ carbohydrate consumed (Nigam, 1998). Increase of aeration rate over than $2.0 \mathrm{~L} / \mathrm{min}$ has caused the yield to decrease by $9.9 \%$. Substrate consumption at aeration rate of $3.0 \mathrm{~L} / \mathrm{min}$ (Figure 5) shows that $C$. utilis cannot utilized the reducing sugar in the pineapple waste medium after $20 \mathrm{~h}$ of fermentation period. The biomass started to decrease while almost $60 \%$ of initial reducing sugar still remained unutilized in the medium. This suggested that fermentation under the aeration rate of $3.0 \mathrm{~L} / \mathrm{min}$ is not suitable, as the over-supply of dissolved oxygen might inhibit the growth of $C$. utilis.

The amount of protein produced was the highest at aeration rate of $2.0 \mathrm{~L} / \mathrm{min}$, i.e. $1.63 \mathrm{~g}$ per $\mathrm{L}$ media, with the 
protein content of $17.14 \%$ (w/w of biomass) (Figure 6). This fermentation condition (900 rpm, $2.0 \mathrm{~L} / \mathrm{min})$ has increased the amount and yield of protein produced by $33.6 \%$ and $55.6 \%$ respectively as compared to the nonoptimized condition (900 rpm, $1.0 \mathrm{~L} / \mathrm{min})$. At the aeration rate of $3.0 \mathrm{~L} / \mathrm{min}$, protein content decreased slightly at the end of fermentation. Intensive aeration led to over-supply of dissolved oxygen, influenced the metabolisme of the yeast (Oura, 1974) and thus, resulted in low yield of protein.

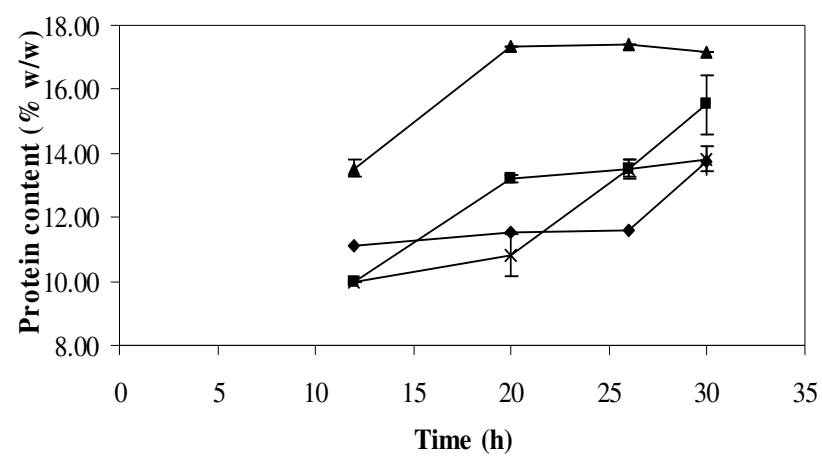

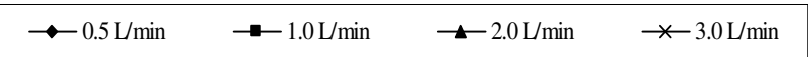

Figure 6: Effects of aeration rate on intracellular protein content of $C$. utilis grown in pineapple waste medium. Fermentation was carried out in $1.5 \mathrm{~L}$ media at $30{ }^{\circ} \mathrm{C}$ with an agitation of $900 \mathrm{rpm}$ for $30 \mathrm{~h}$. Data are mean values \pm standard errors of triplicate samples

\section{CONCLUSIONS}

The present results demonstrate the potential of pineapple waste medium as a substrate for the production of biomass and intracellular protein by $C$. utilis ITM 1017. The pineapple waste medium at $3 \%$ Brix can be used to produce single cell protein and microbial protein.

\section{ACKNOWLEDGEMENTS}

Authors are grateful to the IRPA grant by Ministry of Science, Technology \& Innovation and the Graduate Assistant Scheme for their financial assistances.

\section{REFERENCES}

Feng, Yaoyu, He, Zhimin, Ong, Say Leong, Hu, Jiangyong, Zhang, Zhigang and $\mathrm{Ng}$, Wun Jern (2002). Optimization of agitation, aeration and temperature conditions for maximum $\beta$ - mannanase production, Enzyme and Microbial Technology. 32, 282-289.

Hutagalung, R. I. (2002). Use of carbohydrate residues in Malaysia, downloaded from internet: http://www.unu.udu/unipress/unupbooks/80362e/803 62E0b.htm on $27 / 7 / 2003$.
Kenji Tanaka, Hilary, Z. D. and Ayaaki Ishizaki (1999). Investigation of the utility of pineapple waste material as low-cost substrate for ethanol fermentation by Zygomonas mobilis, Journal of Bioscience and Bioengineering. 87(3), 642-646.

Kratochvilova, A. K. (1990). Yeasts and yeast-like organisms, VCH Publisher, New York.

Lee, Bum-Kyu and Kim, Joong Kyun (2001). Production of Candida utilis biomass on molasses in different culture types, Aquacultural Engineering, 25, 111-124.

Liong, M. T., Rosma, A., Mohd Azemi, M. N. and Wan Nadiah, W. A. (2002). Yeast extract of Saccharomyces cerevisiae and Candida utilis from agrowaste, Proceedings of $25^{\text {th }}$ Malaysian Microbiology Symposium and $5^{\text {th }}$ UNESCO National Workshop for the Promotion of Microbiology in Malaysia, Malaysian Society of Microbiology, Kuala Lumpur.

Loo, C. Y., Rosma, A., Mohd Azemi, M. N. and Wan Nadiah, W. A. (2002). Influence of agrowaste media on intracellular protein of $S$. cerevisiae and $C$. utilis, Proceedings of $25^{\text {th }}$ Malaysian Microbiology Symposium and $5^{\text {th }}$ UNESCO National Workshop for the Promotion of Microbiology in Malaysia, Malaysian Society of Microbiology, Kuala Lumpur.

Miller, G. L. (1959). Use of dinitrosalicyclic acid reagent for determination of reducing sugar. Analytical Chemistry, 31, 426.

Nagodawithana, T. (1992). Yeast-derived flavor enhancer and their probable mode of action, Food Tech, 46(11), 138-143.

Nigam, J. N. (1998). Single cell protein from pineapple cannery effluent, World Journal Microbiology and Biotechnology, 14, 693-696.

Oura, E. (1974). Effect of aeration intensity on the biochemical composition of Baker's yeast. I. Factors affecting the type of metabolisme. Biotechnology and Bioengineering Vol XVI, 1197-1212.

Robinson, H. W. and Hodgen, C. G. (1940). The Biuret reaction of determination of serum protein. I. A study of conditions necessary for the production of the stable color which bears a quantitative relationship to the protein concentration. J. Bio. Chem., 135, 707725. 